Journal. $2004 ; 5$ : 2-6

(in Ukrainian).

5. Chernykh A.M. Gig. i san. 2003 ; 5 : 25-29 (in Russian).

6. Safe Use of Pesticides.

WHO Technical Report Series.

Geneva : WHO, 1991; 813:179 p.

7. Antonovich Ye.A. and

Sedokur L.K. Kachestvo produktov pitaniya $v$ usloviyakh khimizatsii selskogo khoziaistva. Spravochnik [Quality of the Foodstuffs under Conditions of Agricultural Chemicalization] Kiev : Urozhay; 1990 : 240 p. (in Russian).

8. EU - Pesticides database : Maximum Residue Levels. URL : http://ec.europa.eu/food/plant/ pesticides/max_residue_levels/i ndex en.htm.

9. Positive List System for Agricultural Chemical Residues in Foods: Maximum Residue Limits (MRLs). List of

Agricultural Chemicals in Foods. URL : http://www.m5.ws001. squarestart.ne.jp/foundation/se arch.html.

10. Health Canada : Maximum Residue Limits for Pesticides. URL : http://pr-rp.hc-sc.gc.ca/ mrl-Irm/index-eng.php.

11. Codex Alimentarius Codex Pesticides Residues in Food Online Database. URL : http://www.fao.org/fao-whocodexalimentarius/standards/pe stres/pesticides/en/.

12. Perelik pestytsydiv I ahrokhemikativ, dozvolenykh do vykorystannia v Ukraini. Ofitsiine vydannia [List of Pesticides and Agrochemicals Allowed for Application in Ukraine. Official Edition]. Kyiv : Yunivest Media; 2016 : 1026 p. (in Ukrainian).

13. Pesrytsydy. Klasyfikatsiia za stupenem nebezpechnosti : DSanPiN 8.8.1.002-98

[Pesticides. Classification by Safety Degree : State Sanitary Rules and Norms 8.8.1.002-98]. In : Zbirnyk vazhlyvykh ofitsiinykh materialiv z sanitarnykh I protyepidemichnykh pytan [Collection of the Important Official Materials on Sanitary and Anti-Epidemic Issues]. Kyiv ; 2000; 9 (P. 1) : 249-266 (in Ukrainian).

14. Metodicheskie ukazaniya po gigienicheskoi otsenke novykh pestitsidov : MU № 4263-87 [Methodical Directions on the Hygienic Assessment of New Pesticides : MD № 426387]. Kiev ; 1988 : 210 p.

(in Russian).

Надійшла до редакції 16.07.2017

\section{ANALYSIS OF THE DATA OF ULTRASOUND HEART EXAMINATION IN THE WORKERS OF LOCOMOTIVE CREWS DEPENDING ON THEIR SEMIORITY}

Tkachyshyna N.Yu.

\section{АНАЛЛЗ ДАНИХ УЛЬТРАЗВУКОВОГО ДОСЛПДЖЕННЯ СЕРЦЯ У ПРАЦІВНИКІВ ЛОКОМОТИВНИХ БРИГАД ЗАЛЕЖНО ВІД СТАЖУ РОБОТИ}

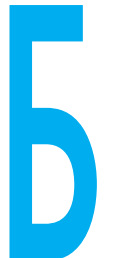

ТКАЧИШИНА Н.Ю.

ПАТ «УЗ» філії «ЦОЗ» Київська клінічна лікарня на залізничному транспорті № 2

УДК 612.176 : 629.4 .072

Ключові слова: локомотивні бригади, умови праці, серцево-судинна система, ультразвукове дослідження серця. езпека перевезень на залізничному транспорті $€$ першочерговим завданням медицини транспортної галузі. Тому вивчення стану здоров'я, попередження, рання діагностика і своєчасне лікування загальносоматичних захворювань у працівників локомотивних бригад (ПЛБ) завжди залишається актуальним завданням транспортної медицини [1]. Визначення патологічних процесів у ПЛБ на ранніх етапах призведе до запобігання виникненню нозологій, що несумісні з виконанням професійних обов'язків означеної категорії. Особливого значення набувають серцево-судинні захворювання

АНАЛИЗ ДАННЫХ УЛЬТРАЗВУКОВОГО ИССЛЕДОВАНИЯ СЕРДЦА У РАБОТНИКОВ ЛОКОМОТИВНЫХ БРИГАД В ЗАВИСИМОСТИ ОТ СТАЖА РАБОТЫ

\section{Ткачишина Н.Ю.}

ПАО «УЗ» филиала «ЦЗО» Киевская клиническая больница на железнодорожном транспорте № 2, г. Киев, Украина Проведено ультразвуковое исследование сердца 398 работникам локомотивных бригад (РЛБ) и 116 инженерно-техническим работникам УЗ. Результаты исследования показали, что у РЛБ имеют место такие изменения: дилатация аорты, ранняя диастолическая дисфункция миокарда, специфическая динамика геометрических изменений левого желудочка с приобретением им формы шара, что является особенностью его моделирования с уменьшением ударного объема на фоне увеличения частоты сердечних сокращений. Подобные изменения прогрессируют у РЛБ с увеличением стажа и способствуют ускоренному темпу старения при наличии вредных условий работы.

Ключевые слова: локомотивные бригады, стаж работы, сердечнососудистая система, ультразвуковое исследование сердца.

ANALYSIS OF THE DATA OF ULTRASOUND HEART EXAMINATION IN THE WORKERS OF LOCOMOTIVE CREWS DEPENDING ON THEIR SENIORITY

Tkachyshyna N.Yu.

Kyiv Clinical Hospital at Railway Transport № 2, "HC" Branch, PC"UR" We performed the ultrasound examination of the heart in 398 workers of locomotive crews (WLC) and 116 engineers and technicians of UR. The results of the study showed that there were the following changes in the WLC: aorta dilatation, early diastolic dysfunction of myocardium, specific dynamics of geometric changes in the left ventricle with the acquisition of a ball shape that was a feature of its modelling with a decrease of the stroke volume in an increase of the heart rate. Similar changes progress in the WLC at the increase of the seniority and contribute to the accelerated rate of aging under harmful working conditions.

Keywords: locomotive crews, seniority, cardiovascular system, ultrasound examination of the heart.

() Ткачишина Н.Ю. СТАТТЯ, 2018. 
(ССЗ) та предиктори виникнення їх і розвитку [2]. Концепція профілактики ССЗ ґрунтується на контролі чинників ризику [3], одним із яких $€$ артеріальна гіпертензія [4].

Тому такими важливими $є$ періодичні медичні огляди ПЛБ [5, 6] та профілактика професійних захворювань, адже означений контингент працює у шкідливих умовах 3 тривалим емоційним й інтелектуальним навантаженням, зосередженим спостереженням, позмінністю та нічними змінами. При цьому провідну роль відіграє зміна реактивності організму під впливом нервово-емоційних та стресових факторів.

Метою проведених нами досліджень $€$ аналіз даних ультразвукового дослідження серця у ПЛБ залежно від стажу роботи.

Матеріали і методи. Загалом було обстежено 398 ПЛБ, які мали стаж роботи не менше 1 року та вік від 19 до 61 року, середній вік становить $39,47 \pm 2,78$. Дані особи склали основну групу.

За контрольну групу, рандомізовану за своїми основними параметрами (стать, вік, стаж роботи), було взято 116 інженерно-технічних працівників Укрзалізниці (ITП). Дана категорія осіб, на відміну від ПЛБ, не зазнає впливу комплексу негативних виробничих факторів, що пов'язані зі специфікою роботи на локомотиві.

Під час проведення досліджень враховували стаж роботи ПЛБ та ІТП. Були сформовані підгрупи (ПГ): ПГ1 - зі стажем роботи <10 років, ПГ2 - 11-20 років, ПГЗ - 21-30 років, ПГ4 $>30$ років.

На ультразвуковому апараті «Vivid-7 Pro» виробництва компанії «General Electric» проводили УЗД серця з вивченням таких показників: ступінь розкриття стулок аортального клапану (AK), діаметр кореня аорти (AO), розмір правого шлуночка у діастолу (ПШ), розмір лівого передсердя (ЛП), товщина міжшлуночкової перетинки у діастолу (МШП), товщина задньої стінки лівого шлуночка у діастолу (ЗСЛШ), загальна товщина стінок лівого шлуночка у діастолу (ТС ЛШ), кінцевий діастолічний розмір лШ (КДР), кінцевий систолічний розмір ЛШ (КСР), кінцевий діастолічний об'єм Лш
(КДО), кінцевий систолічний об'єм ЛШ (КСО), ударний об'єм ЛШ (УО), фракція викиду (ФВ), показник діастолічної функції (E/A), маса міокарду (ММ), індекс маси міокарду (IMM), ЧСС (уд/хв) - частота серцевих скорочень, ХОК (мЛ/Хв) - хвилинний об'єм кровообігу, $\Delta \mathrm{V}-$ співвідношення шлуночків серця (КДР/ПШ), $\Delta \mathrm{P}$ - показник внутрішньоміокардіального напруження (ЗСЛШ+МШП)/КДР).

Результати та обговорення. Для оцінки структурнофункціональних змін міокарда було проведено УЗД серця у ПЛБ та ITП. За результатами обстеження було складено таблицю 1, з якої бачимо, що у представників основної групи має місце достовірне $(p<0,05)$ збільшення діаметра кореня аорти до $(3,92 \pm 0,12)$ см порівняно $з$ контрольною групою, де цей показник становив $(3,52 \pm$ $0,13)$ см. Дилатація кореня

\section{Результати УЗД серця у Пль та ITח (M \pm m)}

\begin{tabular}{|c|c|c|}
\hline Показник & $\begin{array}{c}\text { ПЛБ } \\
(n=398) \\
\end{array}$ & $\underset{\substack{\text { ITח } \\
(n=116)}}{ }$ \\
\hline AK (cM) & $2,02 \pm 0,09$ & $1,98 \pm 0,04$ \\
\hline $\mathrm{AO}(\mathrm{cm})$ & $3,92 \pm 0,12^{*}$ & $3,52 \pm 0,13$ \\
\hline ПШ (см) & $3,08 \pm 0,14$ & $2,86 \pm 0,16$ \\
\hline ЛП (см) & $3,52 \pm 0,14$ & $3,34 \pm 0,12$ \\
\hline МШП (см) & $1,17 \pm 0,02^{*}$ & $1,09 \pm 0,03$ \\
\hline ЗСлШ (см) & $1,15 \pm 0,03^{*}$ & $1,09 \pm 0,02$ \\
\hline ТС ЛШ (см) & $2,32 \pm 0,03$ & $2,18 \pm 0,02$ \\
\hline КДР (см) & $5,14 \pm 0,21$ & $4,95 \pm 0,19$ \\
\hline $\mathrm{KCP}(\mathrm{cm})$ & $2,75 \pm 0,15^{\star}$ & $2,35 \pm 0,12$ \\
\hline КДО (мл) & \begin{tabular}{|c|}
$143,56 \pm$ \\
12,13 \\
\end{tabular} & \begin{tabular}{|c|}
$132,42 \pm$ \\
10,12 \\
\end{tabular} \\
\hline КСО (мл) & $52,43 \pm 5,24^{\star}$ & $41,43 \pm 4,54$ \\
\hline УО (мл) & $92,62 \pm 6,21$ & $91,51 \pm 8,25$ \\
\hline ФВ (\%) & $63,79 \pm 4,21$ & $67,45 \pm 5,76$ \\
\hline$E / A$ & $1,12 \pm 0,07^{*}$ & $1,25 \pm 0,05$ \\
\hline MM (г) & $\begin{array}{c}168,47 \pm \\
11,79^{\star}\end{array}$ & $\begin{array}{c}145,51 \pm \\
12,26\end{array}$ \\
\hline $\begin{array}{l}\mathrm{IMM} \\
\left(\left\ulcorner/ \mathrm{M}^{2}\right)\right. \\
\end{array}$ & $\begin{array}{c}83,25 \pm \\
2,37^{\star}\end{array}$ & $\begin{array}{c}76,42 \pm \\
2,21\end{array}$ \\
\hline $\begin{array}{l}\text { ЧСС } \\
\text { (уд/хв) }\end{array}$ & $73,56 \pm 8,67$ & $65,23 \pm 5,62$ \\
\hline ХОК (л/хв) & $6,84 \pm 0,98$ & $6,11 \pm 0,34$ \\
\hline$\Delta \mathrm{V}$ & $1,67 \pm 0,05$ & $1,73 \pm 0,03$ \\
\hline$\Delta \mathrm{P}$ & $0,45 \pm 0,01$ & $0,44 \pm 0,01$ \\
\hline
\end{tabular}

Примітка:

* - різниця достовірна між аналогічними показниками обстежених груп $(p<0,05)$. аорти призво д ить до розтягнення аортального кільця, що 3 подальшим збільшенням може призвести навіть до виникнення регургітації на аортальному клапані.

Розмір лівого передсердя у діастолу в основній групі недостовірно більший, ніж у контрольній і становить відповідно (3,52 \pm $0,14)$ см та $(3,34 \pm 0,12)$ см.

Також має місце переважання показників, що характеризують розміри порожнин лівого та правого шлуночків. Такі показники, як КДР та КДО, які характеризують діастолу, в основній групі недостовірно більші порівняно з групою ІТП. А показники систоли КСР, що дорівнюють $(2,75 \pm 0,15)$ см та КСО, що складає $(52,43 \pm 5,24)$ мл, достовірно більші $(p<0,05)$ порівняно 3 контрольною групою, де відповідні показники становили $(2,35 \pm 0,12) \mathrm{cm}-$ $\mathrm{KCP},(41,43 \pm 4,54)$ мл - КСО. При цьому систолічна функція лівого шлуночка дещо менша, і ФВ становить $(63,79 \pm 4,21) \%$ порівняно $з$ контрольною групою, де ФВ - $(67,45 \pm 5,76) \%$, але різниця недостовірна.

В основній групі спостерігаємо достовірне $(p<0,05)$ потовщення стінок лівого шлуночка з МШП - $(1,17 \pm 0,02)$ см і ЗСЛШ - $(1,15 \pm 0,03)$ см порівняно 3 аналогічними показниками у контрольній групі: МШП - (1,09 \pm 0,03) см, ЗСЛШ - (1,09 \pm $0,02)$ см. На це саме вказує і показник ТС ЛШ, який у ПЛБ становить $(2,32 \pm 0,03)$ см на відміну від $(2,18 \pm 0,02)$ см у ПЛБ, різниця також достовірна $(p<0,05)$. Має місце достовірне $(p<0,05)$ збільшення $\mathrm{MM}$ $(168,47 \pm 11,79)$ г порівняно 3 ММ у контрольній групі $(145,51 \pm 12,26)$ г та IMМ лівого шлуночка 3 показниками $(83,25 \pm 2,37)$ г/м² у групі ПЛБ щодо показника IMM (76,42 \pm

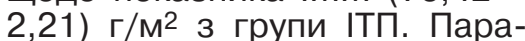
лельно з цими процесами відбувається достовірне $(p<0,05)$ зниження показника $E / A$, який характеризує діастолічну функцію лівого шлуночка. В основній групі він має значення 1,12 $\pm 0,07$, а у контрольній $-1,25 \pm$ 0,05. Такі результати свідчать, що відбувається порушення релаксаційних процесів міокарду зі збільшенням маси фіброзних волокон щодо м'язових. Тобто збільшення маси міокарду лівого шлуночка та порушення діастолічної його 
функції вказує на переважання гіпертрофії зі збільшенням фіброзних волокон.

Разом зі зростанням маси міокарду збільшується, але недостовірно, показник внутрішньоміокардіального напруження $\Delta \mathrm{P}$. Його збільшення у спокої $€$ проявом зниження здатності серцевого м'яза до гіпертрофії, адекватної рівню навантаження. Це може бути причиною зниження насосної функції шлуночка при навантаженні навіть за наявності добрих функціональних можливостей міокарду.

Щодо показника співвідношення об'ємів шлуночків серця, то на фоні збільшення обох шлуночків в основній групі відносно контрольної має місце переважання правого шлуночка при співвідношенні шлуночків $1,67 \pm 0,05$ у ПЛБ та аналогічного показника $1,73 \pm$ 0,03 в ІTП.

Визначаються майже однакові показники ударного об'єму: у ПЛБ $(92,62 \pm 6,21)$ мл, а в ІTП $(91,51 \pm 8,25)$ мл. Але достовірно $(\mathrm{p}<0,05)$ вища ЧСС в Основній групі $(73,56 \pm 8,67)$ уд/хв, порівняно 3 контрольною 3 показником ЧСС $(65,23 \pm 5,62)$ уд/хв, впливає на хвилинний об'єм кровообігу в основній групі і становить $(6,84 \pm 0,98)$ мл/хв порівняно з $(6,11 \pm 0,34)$ мл/хв, що є достовірно більшим $(p<0,05)$ та свідчить про менш економну роботу серця на фоні збільшення маси міокарду та зменшення його релаксації.

Для дослідження впливу стажу роботи ПЛБ на зміни показників УЗД серця було розроблено таблицю 2, з якої бачимо, що у ПЛБ зі збільшенням стажу спостерігається достовірне $(p<0,05)$ розширення кореня аорти 3 (3,42 \pm 0,090) см у групі ПЛБ ПГ1 до $(3,96 \pm 0,06)$ см у групі ПЛБ ПГ4 та збільшення відстані між стулками аортального клапану $3(1,94 \pm 0,02)$ см до $(2,21 \pm$ 0,01) см. При дослідженні виявляються прогресування УЗ-ознаки фіброзу аорти.

у осіб контрольної групи також збільшується діаметр аорти з $(3,44 \pm 0,06)$ см у ПГ1 до $(3,56 \pm 0,06)$ см у ПГ4 та відстань між стулками аортального клапану з $(1,93 \pm 0,02)$ см до Рисунок 1

\section{Динаміка ТC у ПЛБ та ITП зі стажем}

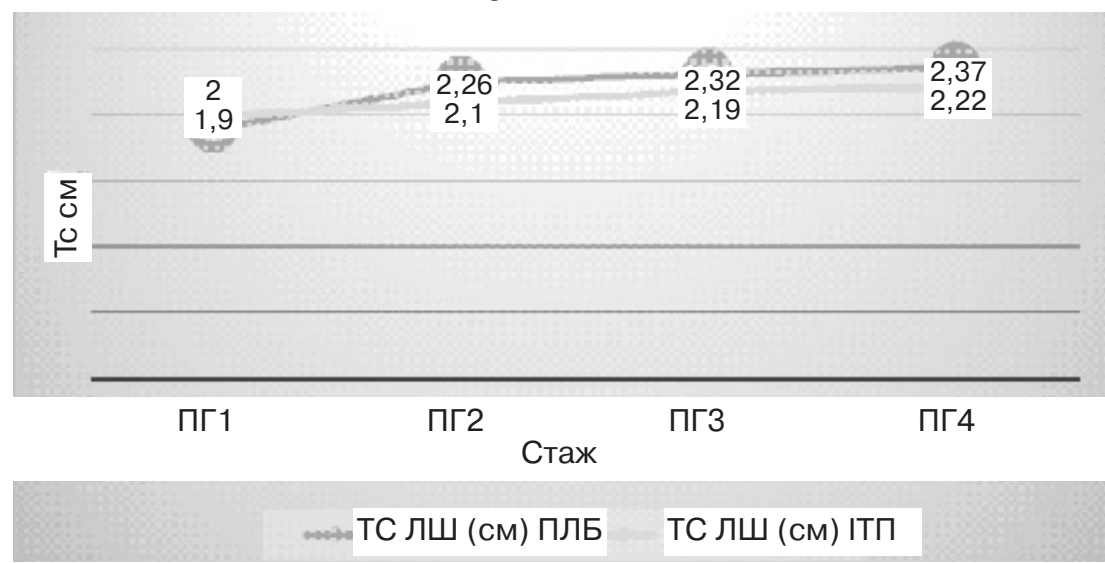

Таблиця 2

Результати УЗД серця у ПЛБ (n=398) та ITП (n=116) залежно від стажу роботи (M \pm m)

\begin{tabular}{|c|c|c|c|c|c|c|c|c|}
\hline \multirow{3}{*}{ Показник } & \multicolumn{8}{|c|}{ Стаж роботи } \\
\hline & \multicolumn{2}{|c|}{ ПГ1 } & \multicolumn{2}{|c|}{ ПГ2 } & \multicolumn{2}{|c|}{ ПГЗ } & \multicolumn{2}{|c|}{ ПГ4 } \\
\hline & ПЛБ $\mathrm{n}=109$ & ITП n=29 & ПЛБ n=84 & ITП n=26 & ПЛБ $\mathrm{n}=123$ & ITП n=35 & ПЛБ n=82 & ITП n=26 \\
\hline $\mathrm{AK}(\mathrm{cm})$ & $1,94 \pm 0,02$ & $1,93 \pm 0,02$ & $1,97 \pm 0,03$ & $1,95 \pm 0,02$ & $2,01 \pm 0,02$ & $1,97 \pm 0,02$ & $2,21 \pm 0,01$ & $1,98 \pm 0,02$ \\
\hline $\mathrm{AO}(\mathrm{cm})$ & $3,42 \pm 0,09$ * & $3,44 \pm 0,06$ & $3,62 \pm 0,07$ & $3,45 \pm 0,06$ & $3,88 \pm 0,06$ & $3,53 \pm 0,05$ & $3,96 \pm 0,06^{\star}$ & $3,56 \pm 0,06$ \\
\hline ПШ (см) & $2,66 \pm 0,03^{*}$ & $2,72 \pm 0,04$ & $2,85 \pm 0,05$ & $2,82 \pm 0,04$ & $3,13 \pm 0,04$ & $2,86 \pm 0,04$ & $3,32 \pm 0,05^{\star}$ & $2,88 \pm 0,04$ \\
\hline ЛП (см) & $3,31 \pm 0,11^{*}$ & $3,29 \pm 0,07$ & $3,43 \pm 0,09$ & $3,32 \pm 0,06$ & $3,55 \pm 0,10$ & $3,35 \pm 0,05$ & $3,65 \pm 0,07^{*}$ & $3,38 \pm 0,06$ \\
\hline МШП (см) & $0,95 \pm 0,03^{*}$ & $1,05 \pm 0,03$ & $1,14 \pm 0,05$ & $1,06 \pm 0,03$ & $1,17 \pm 0,04$ & $1,10 \pm 0,03$ & $1,19 \pm 0,02^{\star}$ & $1,11 \pm 0,03$ \\
\hline ЗСЛШ (см) & $0,95 \pm 0,04^{\star}$ & $0,95 \pm 0,03$ & $1,12 \pm 0,06$ & $1,04 \pm 0,05$ & $1,16 \pm 0,03$ & $1,09 \pm 0,04$ & $1,18 \pm 0,03^{*}$ & $1,11 \pm 0,04$ \\
\hline ТС ЛШ (см) & $1,90 \pm 0,04^{\star}$ & $2,00 \pm 0,03$ & $2,26 \pm 0,06$ & $2,10 \pm 0,05$ & $2,32 \pm 0,04$ & $2,19 \pm 0,04$ & $2,37 \pm 0,03^{*}$ & $2,22 \pm 0,04$ \\
\hline КДР (см) & $4,32 \pm 0,13^{*}$ & $4,35 \pm 0,11$ & $4,75 \pm 0,17$ & $4,41 \pm 0,10$ & $5,34 \pm 0,16$ & $4,96 \pm 0,11$ & $5,53 \pm 0,16^{*}$ & $5,11 \pm 0,10$ \\
\hline $\mathrm{KCP}(\mathrm{cm})$ & $2,33 \pm 0,07^{*}$ & $2,33 \pm 0,05$ & $2,62 \pm 0,08$ & $2,34 \pm 0,06$ & $2,91 \pm 0,09$ & $2,36 \pm 0,07$ & $3,34 \pm 0,06^{*}$ & $2,38 \pm 0,05$ \\
\hline КДО (мл) & $125,72 \pm 9,28^{*}$ & $124,43 \pm 8,15$ & $138,49 \pm 11,58$ & $128,73 \pm 9,52$ & $152,56 \pm 10,36^{\star}$ & $137,11 \pm 9,16$ & $148,54 \pm 9,98$ & $138,104 \pm 9,47$ \\
\hline KCO (мл) & $39,66 \pm 4,68^{*}$ & $39,32 \pm 3,97$ & $46,25 \pm 5,11$ & $40,12 \pm 4,22$ & $54,27 \pm 4,89$ & $42,32 \pm 4,31$ & $58,46 \pm 5,21^{*}$ & $43,18 \pm 4,17$ \\
\hline УО (мл) & $86,45 \pm 4,54^{\star}$ & $84,98 \pm 5,10$ & $92,28 \pm 5,27$ & $88,54 \pm 5,12$ & $98,32 \pm 4,89^{*}$ & $92,95 \pm 5,04$ & $90,52 \pm 5,22$ & $95,87 \pm 5,16$ \\
\hline ФВ (\%) & $67,26 \pm 4,27^{\star}$ & $67,98 \pm 4,87$ & $66,21 \pm 3,51$ & $68,72 \pm 4,27$ & $64,23 \pm 4,39$ & $67,87 \pm 4,12$ & $60,81 \pm 4,47^{*}$ & $66,95 \pm 4,42$ \\
\hline$E / A$ & $1,34 \pm 0,05^{*}$ & $1,31 \pm 0,03$ & $1,25 \pm 0,04$ & $1,26 \pm 0,03$ & $1,16 \pm 0,03$ & $1,25 \pm 0,03$ & $1,03 \pm 0,05^{*}$ & $1,24 \pm 0,03$ \\
\hline MM (г) & $135,28 \pm 12,42^{*}$ & $136,78 \pm 10,11$ & $156,72 \pm 13,68$ & $138,14 \pm 11,23$ & $172,45 \pm 12,51$ & $146,56 \pm 11,16$ & $195,76 \pm 11,96^{\star}$ & $152,41 \pm 10,45$ \\
\hline ППТ ( $\left.\mathrm{M}^{2}\right)$ & $1,85 \pm 0,03$ & $1,83 \pm 0,03$ & $2,02 \pm 0,02$ & $1,88 \pm 0,02$ & $2,12 \pm 0,02$ & $1,87 \pm 0,02$ & $2,21 \pm 0,02$ & $1,85 \pm 0,02$ \\
\hline $\operatorname{IMM}\left(\left\ulcorner/ \mathrm{M}^{2}\right)\right.$ & $73,22 \pm 3,14^{*}$ & $74,73 \pm 3,12$ & $77,47 \pm 3,92$ & $73,89 \pm 3,34$ & $81,25 \pm 3,21$ & $78,38 \pm 3,31$ & $88,72 \pm 2,11^{\star}$ & $81,45 \pm 2,87$ \\
\hline ЧСС (уд/хв) & $65,55 \pm 4,58$ & $67,87 \pm 3,16$ & $71,51 \pm 4,21$ & $68,12 \pm 3,34$ & $73,26 \pm 5,15$ & $68,89 \pm 3,31$ & $78,43 \pm 4,28$ & $69,93 \pm 3,28$ \\
\hline ХOK (л/Хв) & $5,63 \pm 0,09^{*}$ & $5,77 \pm 0,06$ & $6,38 \pm 0,07$ & $5,98 \pm 0,06$ & $7,45 \pm 0,06^{\star}$ & $6,31 \pm 0,05$ & $7,24 \pm 0,05$ & $6,51 \pm 0,05$ \\
\hline$\Delta \mathrm{V}$ & $1,65 \pm 0,02$ & $1,59 \pm 0,02$ & $1,68 \pm 0,02$ & $1,56 \pm 0,02$ & $1,71 \pm 0,01$ & $1,73 \pm 0,02$ & $1,67 \pm 0,01$ & $1,77 \pm 0,02$ \\
\hline$\Delta \mathrm{P}$ & $0,44 \pm 0,01$ & $0,46 \pm 0,01$ & $0,47 \pm 0,02$ & $0,47 \pm 0,01$ & $0,45 \pm 0,01$ & $0,44 \pm 0,01$ & $0,44 \pm 0,01$ & $0,43 \pm 0,01$ \\
\hline
\end{tabular}

Примітка: * - різниця достовірна між аналогічними показниками обстежених груп $(p<0,05)$. 
(1,98 \pm 0,02) см відповідно, різниця недостовірна.

В основній групі відбувається прогресуюче збільшення ТС ЛШ та відповідно складових цього показника: МШП і ЗСлШ $3(0,95 \pm 0,03) \mathrm{cm}$ i $(0,95 \pm 0,04)$ см у ПЛБ ПГ1 до $(1,19 \pm 0,02)$ см і $(1,18 \pm 0,03)$ см відповідно у ПЛБ ПГ4, різниця достовірна $(p<0,05)$. У контрольній групі потовщення стінок ЛШ недостовірне: МШП зростає з $(1,05$ $\pm 0,03)$ см у ПГ1 до $(1,11 \pm 0,03)$ см у ПГ 4, а ЗСЛШ - $3(0,95 \pm$ $0,03)$ см до $(1,11 \pm 0,04)$ см. Зміни ТС у ПЛБ та ІТП з ПГ1 до ПГ4 показано на рисунку 1.

Зі збільшенням стажу роботи ПЛБ прогресують дилатаційні процеси. Це стосується усіх відділів: лівого передсердя та обох шлуночків.

Так, ПШ змінюється $з$ (2,66 \pm $0,03)$ см у ПЛБ ПГ1 до $(3,32 \pm$ $0,05)$ см у ПГ4; ЛП - $3(3,31 \pm$ $0,11)$ см до $(3,65 \pm 0,07) \mathrm{cm}$; КДО - $з(125,72 \pm 9,28)$ мл до $(148,54 \pm 9,98)$ мл; КСО - 3 $(39,66 \pm 4,68)$ мл до $(58,46 \pm$ $5,21)$ мл, різниця достовірна $(p<0,05)$.

При цьому у ПЛБ співвідношення розмірів порожнин лівого та правого шлуночків $\Delta \mathrm{V}$ спершу збільшується 3 (1,65 \pm

\section{Зміни УО у ПЛБ та ITП залежно від стажу роботи}

Рисунок 2

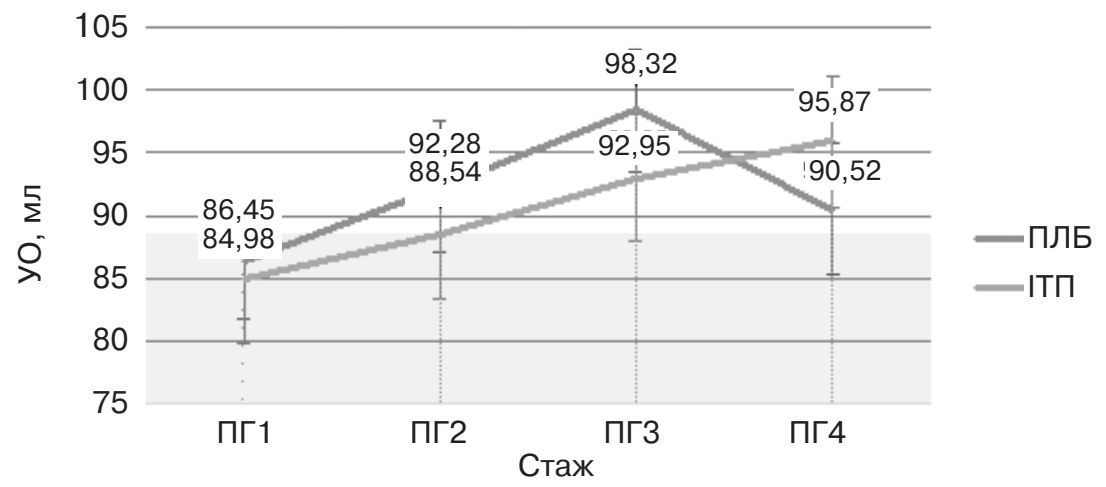

Зміни ФВ у ПЛБ та ITП залежно від стажу роботи

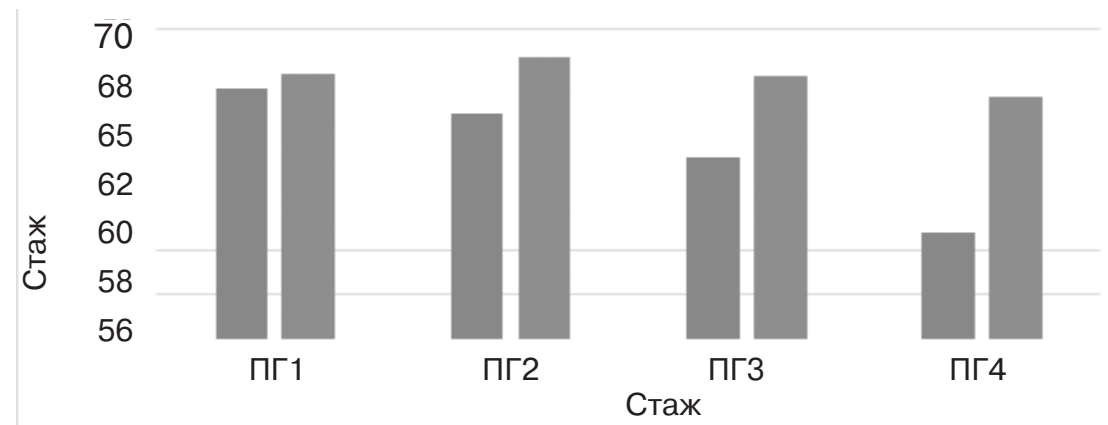

— ФВ(\%)ПЛБ — ФВ(\%) IT ниця достовірна $(p<0,05)$, що видно на рисунках 2 і 3.

у ПЛБ на фоні збільшення розміру обох шлуночків перевага у зростанні у ПГ1, ПГ2, ПГЗ належить лівому шлуночку, а у ПЛБ ПГ4 превалює збільшення правого шлуночка.

Зі збільшенням стажу Лш має тенденцію до утворення форми кулі, що є особливістю моделювання його у ПЛБ. Це відбувається за рахунок спочатку збільшення товщини стінок ЛШ, а потім за умов прогресування фіброзних змін стінок паралельного процесу збільшення розміру порожнини ЛШ у поперековому розмірі.

У контрольній групі відбувається поступове збільшення КДО з $(124,43 \pm 8,15)$ мл у ПГ1 до $(138,104 \pm 9,47)$ мл у ПГ4 та КСO $3(39,32 \pm 3,97)$ мл до $(43,18 \pm 4,1)$ мл. Відповідно збільшується також УО з $(84,98$ $\pm 5,10)$ мл у ПГ1 до $(95,87 \pm$ $5,16)$ мл у ПГ4. Різниця недостовірна

При порівнянні ХOK у ПЛБ в усіх чотирьох стажових групах на фоні описаних змін УО та показника ЧСС, що зростає, виявляється його збільшення від $(5,63 \pm 0,09)$ л/хв у ПГ1 до $(6,38 \pm 0,07)$ л/хв у ПГ2 і до $(7,45 \pm 0,06)$ л/хв у ПГЗ. Але у ПГ4 ХОК зменшується до $(7,24$ $\pm 0,05)$ л/хв, причому за рахунок зниження УО незважаючи на подальше зростання ЧСС, що вказує на неекономну роботу серця та зниження адаптаційних можливостей міокарду.

У ІTП відзначається поступове зростання ХOK $3 \quad(5,77 \pm$ $0,06)$ л/хв у ПГ1 до $(6,51 \pm 0,05)$ л/хв у ПГ4.

Показник діастолічної функції E/А зі збільшенням стажу у ПЛБ зменшується з 1,34 \pm 0,05 у ПГ1 до 1,25 $\pm 0,04$ у ПГ2, 1,16 \pm 0,03 у ПГЗ, 1,03 \pm 0,05 у ПГ4, що вказуе на підвищення жорсткості міокарду та зменшення кількості еластичних волокон. Різниця між ПГ1 та ПГ4 достовірна $(\mathrm{p}<0,05)$.

У ІТП також має місце зниження показника E/A 3 1,31 0,03 у ПГ1 до 1,24 \pm 0,03 у ПГ4 3 недостовірною різницею.

Як раніше відзначалося, МШП та ЗСЛШ у ПЛБ зі стажем збільшуються, причому порівняно з показниками у групі ПЛБ ПГ1 з групою ПЛБ ПГ4 достовірно ( $p<0,05)$. Отже, достовірно $(p<0,05)$ збільшуються і такі 
показники, як ММ - $3(135,28 \pm$ $12,42)$ г у групі ПЛБ ПГ1 до $(195,76 \pm 11,96)$ г у групі ПЛБ ПГ4 та IMМ $3(73,22 \pm 3,14) г / \mathrm{M}^{2}$ до $(88,72 \pm 2,11)$ г/м² відповідно, але при формуванні гіпертрофії збільшується жорсткість міокарду за рахунок фіброзної тканини, про що свідчить зменшення показника діастолічної функції міокарду.

У групі ІТП ММ зі збільшенням стажу зростає недостовірно $3(136,78 \pm 10,11)$ г у ПГ1 до $(152,41 \pm 10,45)$ гу ПГ4, а також IMM має відповідно подібне недостовірне зростання 3 $(74,73 \pm 3,12)$ г/м ${ }^{2}$ до $(81,45 \pm$

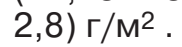

Динаміка змін $\Delta \mathrm{P}$ у групах ПЛБ та ІТП залежно від стажу практично однакова.

\section{Висновки}

1. У ПлБ визначається дилатація аорти та її фіброзні зміни, що впливає на гемодинаміку, адже зі зменшенням еластичних властивостей аорти та збільшенням ступеня її фіброзу збільшується постнавантаження, що є передумовою розвитку гіпертрофії лівого шлуночка. Паралельно з розтягненням аортального кільця збільшується відстань між стулками клапану, формуються передумови для виникнення зворотного току на аортальному клапані.

2. У ПЛБ зі збільшенням стажу збільшується товщина стінок ЛШ, з'являється його діастолічна дисфункція 3 порушенням його наповнення, що пояснюється зростанням жорсткості міокарда і втратою його еластичних властивостей.

3. Зі збільшенням стажу у Пль за рахунок специфічної динаміки геометричних змін ЛШ відзначаються характерні зміни його порожнини, яка набуває форму кулі, що є особливістю моделювання ЛШ у ПЛБ, яке призводить до зниження УО.

4. На тлі прогресуючого збільшення розміру обох шлуночків у ПЛБ перевага у зростанні належить лівому шлуночку, а у ПЛБ зі стажем понад 30 років превалює збільшення правого шлуночка.

5. Означені зміни у ПлБ набувають динаміку зі збільшенням стажу та мають прогресуюче зростання у ПЛБ зі стажем роботи від 21 року за наявності шкідливих умов та характеру праці ПЛБ з присут- ністю емоційного та інтелектуального навантаження. Тож на тлі зростання ЧСС при зниженні адаптаційно-компенсаторних можливостей ССС у ПЛБ починають відбуватися зміни у молодшому віці, ніж в ITП. Під впливом несприятливих умов роботи природні процеси старіння з погіршенням функціонування СCC у ПЛБ починаються вже 340 років та мають прискорений темп порівняно з ІТП.

ЛІТЕРАТУРА

1. Железнодорожная медицина. Медицинское

обследование безопасности движения поездов :

руководство / под ред. В.М. Сибилева, Ю.Н. Коршунова, А.З. Цфасмана. M., 1990 .

2. Піх Б.П., Думський В.П. Надійність людського чинника як основа безпеки руху. Медицина залізничного транспорту України. 2004. № 3. C. 60-61.

3. Campbell N.R., Khan N.A., Grover S.A. Barriers and remaining questions on assessment of absolute cardiovascular risk as a starting point for interventions to reduce cardiovascular risk. J. Hypertension. 2006. Vol. 24, № 9. P. 1683-1685.

4. Dzau V., Braunwald E. Resolved and unresolved issues in the prevention and treatment of coronary artery disease: a workshop consensus statement. Am. Heart J. 1991. Vol. 121 (4 Pt. I). P. 1244-1263.

5. Про затвердження Порядку проведення медичних оглядів працівників певних категорій : Наказ Міністерства охорони здоров'я України від 21.05.2007 p. № 246. URL : http://zakon2.rada.gov.ua/laws/ show/z0846-07

6. Про затвердження

Порядку проведення медичних оглядів працівників певних категорій залізничного транспорту, метрополітенів та підприємств міжгалузевого промислового залізничного транспорту України : Наказ Міністерства транспорту та зв'язку України від 29.04.2010 p. № 240. URL : http://zakon3.rada.gov.ua/laws/ show/z0537-10.

REFERENCES

1. Sibileva V.M.,

Korshuno-va Yu.N. and

Tsfasman A.Z. (eds.)
Zheleznodorozhnaya meditsina.

Meditsinskoe

obsledovanie bezopasnosti dvizheniya poezdov: rukovodstvo [Railway Medicine. Medical Examination of Safety of Train Movement : Guide]. Moscow ; 1990. (in Russian).

2. Pikh B.P. and Dumskyi V.P. Medytsyna zaliznychnoho transportu Ukrainy. 2004 ; 3 : 60-61 (in Ukrainian).

3. Campbell N.R., Khan N.A. and Grover S.A. J. Hypertension. 2006 ; 24 (9) : 1683-1685.

4. Dzau V. and Braunwald E. Am. Heart J. 1991 ; 121 (4 Pt. I) : 1244-1263.

5. Pro zatverdzhennia Poriadku provedennia medychnykh ohliadiv pratsivnykiv pevnykh katehorii : Nakaz Ministerstva transport ta zviazku Ukrainy vid 21.05.2007 № 246 [On the Adoption of the Order of Medical Examinations in the Employees of Certain Categories : Order of the Ministry of Public Health of Ukraine № 246, May 21, 2007]. URL : http://zakon2.rada.gov.ua/laws/ show/z0846-07 (in Ukrainian).

6. Pro zatverdzhennia

Poriadku provedennia medychnykh ohliadiv pratsivnykiv pevnykh katehoriy zaliznychnoho transportu, metropoliteniv ta pidpryiemstv mizhhaluzevoho promyslovoho zaliznychnoho transport Ukrainy : Nakaz Ministerstva transport ta zviazku Ukrainy vid 29.04.2010 № 240 [On the Adoption of the Order of Medical Examinations in the Employees of Certain Categories of Railway Transport, Subway, and Enterprises of Interindustrial Railway Transport of Ukraine : Order of the Ministry of Transport and Communications № 240, April 29, 2010]. URL : http://zakon3.

rada.gov.ua/laws/show/z053710 (in Ukrainian).

Надійшла до редакції 18.09.2017 